\title{
Studies Regarding the Effect of Organic Fertilizers on a Permanent Grassland in Petrova, Maramureș
}

\author{
Adela L. BOTIŞ, Gheorghe MIHAI, Nicuşor SIMA*, Doru CRISTE, Ion MIHALCA, Iulia MEDREA, Bogdan \\ FĂGĂDAR
}

Faculty of Animal Science and Biotechnologies, University of Agricultural Sciences and Veterinary Medicine, 3-5 Mănăștur Street, 400372 Cluj-Napoca, Romania

*Corresponding author, e-mail: flaviusima@yahoo.com

Bulletin UASVM Animal Science and Biotechnologies 72(2) / 2015

Print ISSN 1843-5262; Electronic ISSN 1843-536X

DOI:10.15835/buasvmcn-asb:11420

\begin{abstract}
Grasslands have a great importance for humans around the world being the beginning of many of our food products. Since there is a direct connection between soil, plant and climate, scientists have become concerned of this interaction and studies have been conducted to describe this connection and to improve output in grasslands with the best possible measures. The experiment set up in Petrova, Maramureş in the autumn of 2012 was used to obtain information on how different types of manure influence vegetation and the output on permanent grasslands. Since there are other studies in this field, in different areas of Romania and in other countries, results can be compared so that a bigger picture can be obtained on how organic fertilizers influence the quality and quantity of forage.
\end{abstract}

Keywords: grassland, Maramureş, organic fertilizers.

\section{INTRODUCTION}

Technological development, mechanization, agrochemical substances and, more recently, genetic findings have permitted a constant growth of grassland productions and led to structural changes in agriculture (Bogdan, 2012). A form of maintaining the balance between environmental health and human needs for food products and fodder is by using natural resources and giving back what nature provides to humans.

Scientific interest in grasslands began in the $20^{\text {th }}$ century when the connection between the structure of the vegetation and the soil and climatic conditions in which it develops was shown (Samfira et al., 2011). Recent challenges in the field concern environmental protection and food safety, and a way to ensure these needs is by adopting the ecological strategy in producing and processing materials, in this case, sward. It is worth noting that the rediscovery of organic nutrients as a source of essential nutrients did not come from agriculture but from ecology after agricultural research under government direction had the industrialization of agriculture assigned as its chief task (Paungfoo-Lonhienne et al., 2012).

Increasing production on grasslands and fighting degradation of the soil and vegetation can be achieved by shifted from mineral treatments to organic ones, as mineral fertilizers have a negative influence on the environment especially if not used properly. Ingested nitrate affects mammals, is a causal agent for carcinogenesis and other diseases, and exposure to excessive quantities of reactive $\mathrm{N}$ shortens our life expectancy (Sutton et al., 2011).

Since vegetation in grasslands is the main source of fodder for animals, especially those on farms, it is of major importance to use the best treatment for soil and grasslands so that it can provide sufficient and safe fodder.

Research concerning vegetation and grassland in the Maramureş area began two centuries ago, due to its complexity and richness in flora. Most of the studies undertaken here described the 
vegetation in different geographical structures. Along with the accumulation of knowledge about vegetation in Maramureş, research developed to drawing technologies by improving permanent grassland and founding temporary ones. Most of the research in Maramureş was developed in the $18^{\text {th }}$ and $19^{\text {th }}$ centuries, recently becoming an area of interest for future studies.

Studies carried out in different levels of vegetation, on a high number of grassland types, show the positive effect of manure on the dry matter content of herbage (Bogdan, 2012). The quantity of dry matter in permanent grasslands differs from one experiment to another due to different climate conditions. Dry matter in permanent grasslands can vary from $2 t$ /ha to $13 t /$ ha (Păcurar, 2005).

Research concerning organic fertilization of permanent grassland in Slovakia established that as manure rates rise, the contents of dry matter (DM) and fibre decrease, while crude protein (CP) content increases (Beňová et al., 2013).

\section{MATERIALS AND METHODS}

Recognizing the importance of healthy soils, plants, animals and further on the chain, the quality of food and environment, it is timely to draw on diverse nutrient sources to prevent pollution and degradation of natural resources. Since it is already proved that the ecosystem cannot last any longer on synthetic supplies, organic farming could be the starting point for creating balance in nature.

The environmental conditions in Petrova are highly representative for the Maramures Depression this being the main reason why Petrova was chosen as the location for the experiment. Petrova is placed on the left bank of the Viseu river, about $12 \mathrm{~km}$ from its confluence with the Tisa river, $100 \mathrm{~km}$ from Baia Mare, the capital city of the county, $35 \mathrm{~km}$ from Sighetu Marmatiei, the former capital of historical Maramures, and $24 \mathrm{~km}$ away from the town of Viseu de Sus. Geographically, according to the coordinates established in 1933,
Petrova is at $24^{\circ} 11^{\prime} 50^{\prime \prime}$ eastern longitude and $47^{\circ}$ $49^{\prime} 40^{\prime \prime}$ northern latitude, at $357.74 \mathrm{~m}$ above the sea level (Criste et al., 2013).

The experiment was established on a permanent grassland in the climate conditions of Petrova in October 2012. The experiment is set up using the randomized blocks method, in 3 blocks with 13 variants, each variant being treated exclusively organically. Each variant of the experiment has a surface of $25 \mathrm{~m}^{2}$ and it is divided in 2 equal variants, one being harrowed (V1 V13) and the other un-harrowed (V'1 - V'13). The fertilizers used in the process are manure from the livestock in Petrova's organic farm. The field has been treated with manure every year in autumn since the experiment was set up; the studies are continued to this day. Taking into consideration the chemical composition of manure (Tab.1), the treatment applied on each variant was established as follows: V1 is the witness variant and it has no treatment at all, on V2 20t/ha manure was applied, on V3 30t/ha manure, on V4 40t/ha manure. Starting with the $5^{\text {th }}$ variant, 20 t/ha liquid manure was used for V5, 30t/ha for V6 and $40 \mathrm{t} /$ ha for V7. For the next variants a mixture of fertilizers was used, i.e. mash manure (gülle) as follows: V8 a mixture of 10t/ha manure and 10t/ ha of liquid manure, V9 15t/ha manure and 15t/ha liquid manure, V10 20t/ha manure and 20t/ha of liquid manure. In the last three variants only fresh manure was used, in quantities as follows: 20t/ ha fresh manure for V11, 30t/ha fresh manure for V12 and 40t/ha fresh manure for V13. To establish the production of the grassland, the direct method of repeated cuts was used. The obtained data were statistical analysed using ANOVA and DUNCAN test.

\section{RESULTS AND DISCUSSION}

By the mid-20 ${ }^{\text {th }}$ century, plant nutrition was focused on mineral and synthetic fertilizers, but research on the uptake of organic molecules established fundamental knowledge of plant

Tab.1. The chemical composition of the organic fertilizer (kg/t of manure) (Mihai, 2006)

\begin{tabular}{cccccc}
\hline TYPE OF MANURE & $\mathrm{N}$ & $\mathrm{P}_{2} \mathrm{O}_{5}$ & $\mathrm{~K}_{2} \mathrm{O}$ & $\mathrm{CaO}$ & Organic matter \\
\hline Manure & 6,5 & 4,2 & 5,3 & 2,8 & 280 \\
\hline Manure slurry & 4,7 & 1,2 & 2,1 & 0,7 & 54 \\
\hline Mash manure (gülle) & 4,5 & 1,8 & 4,2 & 2,3 & 36 \\
\hline
\end{tabular}


function (Paungfoo-Lonhienne et al., 2012). Although the basis for the use of organic fertilizers was indeed studied, organic agriculture started to develop and raise more interest in the last decades only.

The role of animals in the organic system is to facilitate nutrient recycling and the potential of this process through fertilizer application is high (Samuil and Vîntu, 2006). Even studies in Maramureş were concerned mostly with increasing productivity in grasslands by using synthetic fertilizers. Because of this situation, currently agricultural practices recommend reducing the use of chemical fertilizers and promote other sources of fertilizer (Tarcău et al., 2012).

Results obtained in the first trial varied between 0.99 and $3.54 \mathrm{t} \cdot \mathrm{ha}^{-1} \mathrm{DM}$ yield (Tab.2).

It is interesting to point out the favourable effect of manure used as such or as a mixture upon the production of DM. Significant growths in yield were obtained as compared to those harvested from the control variant in 8 of the 9 variants in which manure was used as a fertilizer. These growths varied between 1.31 and $2.40 \mathrm{t} \cdot \mathrm{ha}^{-1} \mathrm{DM}$ yield. In the variants with significant increase in yield, the lowest growth was obtained in the one fertilized with 40t/ha manure and the largest one on the variant fertilized with the same quantity of fresh manure. In the variants which were fertilized with a mix of manure and liquid fertiliser on V9 (15t/ha manure and 15t/ha liquid manure) a significant growth in yield of $1.08 \mathrm{t} \cdot \mathrm{ha}^{-1} \mathrm{DM}$ was obtained.

Fertilization with gülle in doses of 20 and 40 t/ha (V5-V7) in the first year of trial growths led to insignificant differences in growth compared with the control (Tab. 2).

DUNCAN test was carried out to establish the difference between the effect of the treatments which determined growths or/and disparities in yield compared with the witness variant (Tab.3).

Based on the analysis of the results, it can be pointed out that there are no significant differences of harvest between the levels of fertilisation with 30 and 40t/ha. Between the harrowed variants fertilized with mash manure a significant difference between the variants treated with $15 \mathrm{t} /$ ha manure and $15 \mathrm{t} /$ ha liquid manure V9 and the one with 20t/ha manure and 20t/ha liquid manure - V10 was noticed.

In the case of the un-harrowed variants (V'1-V'13), the yield growth was lower for most of the variants tested compared with the control and also with the harrowed variants fertilised with the same doses of fertilizer.

The ones fertilised with mash manure V'5 and V' 6 are exceptions: on growths in production compared with the control (un-fertilized and un-harrowed) and also with the similar variants fertilized and harrowed was noticed in these cases. For these two variants it is notable that on the variant fertilised with $20 \mathrm{t} / \mathrm{ha}\left(V^{\prime} 5\right)$ the growth

Tab.2. Variation with fertilization dose in the DM yield ( $\left(\cdot \mathrm{ha}^{-1}\right)$

\begin{tabular}{ccccc}
\hline Fertilization & $\begin{array}{c}\text { DM yield } \\
\left(\mathrm{t} \cdot \mathrm{ha}^{-1}\right)\end{array}$ & $\begin{array}{c}\text { Yield } \\
\%\end{array}$ & $\begin{array}{c}\text { Differences } \\
+/-\left(\mathrm{t} \cdot \mathrm{ha}^{-1}\right)\end{array}$ & Significance \\
\hline V1 & 1.14 & 100.0 & 0.00 & Control. \\
\hline V2 & 2.87 & 251.8 & 1.73 & $* * *$ \\
\hline V3 & 2.53 & 221.6 & 1.39 & $* * *$ \\
\hline V4 & 2.45 & 215.2 & 1.31 & $* * *$ \\
\hline V5 & 1.64 & 143.6 & 0.50 & - \\
\hline V6 & 0.99 & 87.1 & -0.15 & - \\
\hline V7 & 1.29 & 113.2 & 0.15 & - \\
\hline V8 & 2.70 & 236.5 & 1.56 & $* * *$ \\
\hline V9 & 2.22 & 194.7 & 1.08 & $* *$ \\
\hline V10 & 3.06 & 268.1 & 1.92 & $* * *$ \\
\hline V11 & 2.92 & 256.1 & 1.78 & $* * *$ \\
\hline V12 & 3.20 & 280.7 & 2.06 & $* * *$ \\
\hline V13 & 3.54 & 310.2 & 2.40 & $* * *$ \\
\hline LSD (p 5\%)0.65 LSD (p 1\%) 0.88; LSD (p 0.1\%) 1.18 & &
\end{tabular}


in yield compared with the control was better than the same harrowed variant V5 harrowed. For unharrowed V'6 fertilized with mash manure growth in harvest compared with the un-harrowed control was obtained. On harrowed field for the same dose of fertiliser, DM production was lower in comparison with the control.

On the un-harrowed field, statistical growths in production varied between significant ( $V^{\prime} 4$, $\left.V^{\prime} 10, V^{\prime} 12\right)$, significantly distinctive (V'11) and highly significant (V'13). The lowest growth in production was obtained on the variant fertilized with 40t/ha mash manure and the highest growth on the one fertilized with 40t/ha fresh manure.

Similar results were obtained by by Sima in 2003 (Sima et al., 2003), by Samuil in 2006 (Samuil and Vîntu, 2006), by Ludu in 2010 (Ludu, 2010) and by Anca Bogdan in 2012 (Bogdan, 2012). In
Bulgaria, on a Festuca rubra L.- Agrostis capillaris L. meadow, Todorova obtained an average of 3.35t/ha of dry matter on an eight year trial using organic fertilizers.

\section{CONCLUSION}

Based on the results obtained in Petrova, organic fertilizers and their level influence significantly DM yields. Štỳbnarová Marie reached the same conclusion in 2005 regarding the influence of the levels of organic fertilizers upon DM yield.

For the un-harrowed variants (V'1-V'13) yield growths were lower for most variants tested in comparison with un-harrowed control and with harrowed variants fertilized similarly.

All the un-harrowed variants fertilised with mash manure recorded growths in yield in

Tab.3. The influence of fertilization on DM yields ( $t$-ha- 1 )

\begin{tabular}{cccccc}
\hline $\begin{array}{c}\text { Fertilization } \\
(\mathrm{F})\end{array}$ & $\begin{array}{c}\text { DM yield } \\
\left(\mathrm{t} \cdot \mathrm{ha}^{-1}\right)\end{array}$ & \multirow{2}{*}{$\begin{array}{c}\text { TSD } \\
\mathrm{p}=0.05\end{array}$} & $\begin{array}{c}\text { Fertilization } \\
(\mathrm{F})\end{array}$ & $\begin{array}{c}\text { DM yield } \\
\left(\mathrm{t} \cdot \mathrm{th}^{-1}\right)\end{array}$ & $\begin{array}{c}\text { TSD } \\
\mathrm{p}=0.05\end{array}$ \\
\cline { 1 - 3 } $\mathrm{V} 6$ & $0.99 \mathrm{~A}$ & & $\mathrm{~V} 8$ & $2.70 \mathrm{CDE}$ & 0.75 \\
\hline $\mathrm{V} 1$ & $1.14 \mathrm{~A}$ & 0.65 & $\mathrm{~V} 2$ & $2.87 \mathrm{CDEF}$ & 0.75 \\
\hline $\mathrm{V} 7$ & $1.29 \mathrm{~A}$ & 0.68 & $\mathrm{~V} 11$ & $2.92 \mathrm{CDEF}$ & 0.76 \\
\hline $\mathrm{V} 5$ & $1.64 \mathrm{AB}$ & 0.70 & $\mathrm{~V} 10$ & $3.06 \mathrm{DEF}$ & 0.76 \\
\hline $\mathrm{V} 9$ & $2.22 \mathrm{BC}$ & 0.72 & $\mathrm{~V} 12$ & $3.20 \mathrm{EF}$ & 0.76 \\
\hline $\mathrm{V} 4$ & $2.45 \mathrm{CD}$ & 0.73 & $\mathrm{~V} 13$ & $3.54 \mathrm{~F}$ & 0.75 \\
\hline V3 & $2.53 \mathrm{CDE}$ & 0.74 & - & - & - \\
\hline
\end{tabular}

Tab.4. Variation with fertilization dose in the DM yield ( $\left(\cdot \mathrm{ha}^{-1}\right)$ un-harrowed field

\begin{tabular}{|c|c|c|c|c|}
\hline $\begin{array}{c}\text { Fertilization / } \\
\text { no harrowed }\end{array}$ & $\begin{array}{c}\text { DM yield } \\
\left(\mathrm{t} \cdot \mathrm{ha}^{-1}\right)\end{array}$ & $\begin{array}{c}\text { Yield } \\
\% \\
\end{array}$ & $\begin{array}{l}\text { Differences } \\
+/-\left(\mathrm{t} \cdot \mathrm{ha}^{-1}\right)\end{array}$ & Significance \\
\hline$V^{\prime} 1$ & 1.18 & 100 & 0 & Control \\
\hline$V^{\prime} 2$ & 1.98 & 168 & 0.8 & - \\
\hline$V^{\prime} 3$ & 2.17 & 184.4 & 0.99 & - \\
\hline$V^{\prime} 4$ & 2.57 & 218.1 & 1.39 & $*$ \\
\hline $\mathrm{V}^{\prime} 5$ & 1.83 & 155.5 & 0.65 & - \\
\hline$V^{\prime} 6$ & 1.33 & 112.7 & 0.15 & - \\
\hline$V^{\prime} 7$ & 1.29 & 109.9 & 0.12 & - \\
\hline V'8 & 2.13 & 180.7 & 0.95 & - \\
\hline$V^{\prime} 9$ & 1.95 & 165.7 & 0.77 & - \\
\hline$V^{\prime} 10$ & 2.52 & 214.4 & 1.35 & $*$ \\
\hline$V^{\prime} 11$ & 2.88 & 244.5 & 1.7 & $* *$ \\
\hline$V^{\prime} 12$ & 2.32 & 196.9 & 1.14 & $*$ \\
\hline V'13 & 3.43 & 291.8 & 2.26 & $* * *$ \\
\hline
\end{tabular}


comparison with the control and with harrowed variants treated with the same doses and fertiliser.

The highest growths in yield with highly significant statistical significance $(\mathrm{p}<0.001)$ were obtained on the variant V13 treated with 40t/ha fresh manure.

\section{REFERENCES}

1. Beňová D., Jančová M., Pollák Š. (2013). Manure application level and its effects on permanent grassland herbage quality, NutriNET, Nitra, 7-10.

2. Bogdan Anca (2012). Cercetări privind folosirea şi menținerea pajiștilor montane cu low-put, PhD Thesis at The University of Agricultural Science and Veterinary Medicine, Cluj-Napoca.

3. Botiş AL, Mihai Gh, Sima N, Criste D, Făgădar B (2015) Permanent Grassland History Researches in Maramureş. Scientific Papers: Animal Science and Biotechnologies. 48 (1): $11-13$.

4. Criste D., Gh. Mihai, N. Sima, Iulia Medrea, Adela Botiş, Rodica Sima (2013). Studies regarding the influence of organic and mineral fertilization on the permanent grassland from Maramureș Depression-Petrova, Bulletin UASVM AS-B 70(1-2)/2013.

5. Ludu O.D. (2010). Cercetări privind influența unor inputuri tehnologice asupra producției, calității, valorii furajere şi gradului de conversie a pajiştilor de Festuca rubra, PhD Thesis at The University of Agricultural Science and Veterinary Medicine, Cluj-Napoca.

6. Mihai Gh. (2006). Cultura pajiştilor, Ed. AcademicPres, Cluj-Napoca.

7. Păcurar F (2005). Cercetări privind dezvoltarea sustenabilă a satului Ghețari, comuna Gârda prin îmbunătățirea pajiştilor naturale şi a unor culturi agricole. PhD Thesis at University of Agricultural Science and Veterinary Medicine Cluj-Napoca.

8. Paungfoo-Lonhienne C., Visser J., Lonhienne T.G.A., Schmidt Susanne (2012). Past, present and future of organic nutrients, Springer Science plus Business Media B.V. 2-14, DOI: 10.1007/s11104-012-1357-6.

9. Samfira I., T. Maruşca, A. Moisuc, Monica Hărmănescu, M. Herbei, Veronica Sărățeanu, C. Popescu (2011), Elemente metodologice aplicate în cercetarea pajiştilor, Timişoara.

10. Samuil C., V. Vîntu (2006). Environmental impact and yield of permanent grasslands: an example of Romania, http://dx.doi.org/10.5772/52006.

11. Sima N., I. Rotar, Mariana Rusu, Roxana Vidican (2003). The influence of both some technological inputs and harvesting phenological phase on forage yield from a Festuca rubra pasture (Cindrel Mountains - Romania). 2-nd International Symposium Prospects for the 3-rd Millenium Agriculture - Bulletin of UASMV Cluj Napoca.

12. Sutton M.A, Oenema O., Erisman JW, Leip A, van Grinsven H, Winiwarter W, Too much of a good thing, 2011, Nature, 472:159-161.

13. Štỳbnarová Marie, M. Mičová, K. Fiala, H. Karabcová, 0. Látal, J. Pozdíšek (2014). Effect of organic fertilizers on botanical composition of grassland, herbage yield and quality, Agriculture, 60 (3):87 - 97, DOI: 10.2478/agri2014-0010.

14. Tarcău Doina, M. Stavarache, C. Samuil, V. Vîntu (2012). Influence of organic inputs on the quality of forages produced on a grassland of Nardus stricta L. and Festuca rubra L., Lucrări ştiinţifice - Seria Zootehnie, vol. 58, Iaşi.

15. Todorova P, Pavlov D, Petrova I (2003). Productivity and botanical composition of permanent grassland in the Central Balkan Mountais. Grassalnd Science in Europe 8: 64-66 